\title{
HUBUNGAN ANTARA KECERDASAN EMOSI DENGAN PERILAKU PENYESUAIAN DIRI YANG SALAH PADA SISWA SMP NEGERI 6 KOTA BENGKULU
}

\author{
Laras Rama Tania, Hadiwinarto, Rita Sinthia \\ Prodi Bimbingan dan Konseling Fakultas Keguruan dan Ilmu Pendidikan \\ Universitas Bengkulu \\ Larasrama1@gmail.com,Hadiwin@unib.ac.id, ritasinthia@unib.ac.id
}

\begin{abstract}
ABSTRAK
Penelitian ini bertujuan untuk mendeskripsikan hubungan antara kecerdasan emosi dengan perilaku penyesuaian diri yang salah. Populasi dalam penelitian ini adalah siswa kelas VIII SMP Negeri 6 Kota Bengkulu Tahun Ajaran 2018/2019 sejumlah 171 orang siswa. Sampel penelitian berjumlah 120 siswa yang diambil menggunakan teknik simple random sampling.Teknik analisis data menggunakan skala kecerdasan emosi dan skala penyesuaian diri yang salah. Data yang telah dikumpulkan dianalisis dengan menggunakan analisis korelasi product moment. Hasil perhitungan menunjukkan bahwa koefisien korelasi sebesar -0,402 dengan $\mathrm{p}=0,000(\mathrm{p}<0,05)$. Hasil penelitian menunjukkan terdapat hubungan negatif yang signifikan antara kecerdasan emosi dengan perilaku penyesuaian diri yang salah. Artinya semakin tinggi kecerdasan emosi maka semakin rendah perilaku penyesuaian diri yang salah.
\end{abstract}

Kata kunci: korelasional, kecerdasan emosi, perilaku penyesuaian diri yang salah

\section{THE CORRELATION BETWEEN EMOTIONAL INTELLIGENCE AND MALADJUSTMENT AT STUDENTS OF SMP N 6 BENGKULU}

\begin{abstract}
The objectives of this study were to describe the correlation between emotional intelligence and maladjustment. The population of the study were eight grade students of SMP N 6 BKL in the academic year 2018/2019. The sample of this study were 120 students taken by using simple random sampling. The data were collected by using emotional intelligence scale and maladjusment scale. The data were analyzed by using Pearson's Product- Moment Correlation. The result of this study showed that correlational cpefficient was $r_{x y}=-0,402$ with $p=0,000$ $(\mathrm{p}<0,05)$. It meant that there was a correlational between emtional intelligence and maladjustment. So, it can be concluded that if the intelligence was higher, then maladjusment was lower.
\end{abstract}

Keywords: correlation, emotional intelligence, maladjustment 


\section{Pendahuluan}

Masa remaja adalah masa peralihan dari kanak-kanak menuju dewasa. Seorang remaja tidak lagi dapat dikatakan sebagai kanak-kanak, namun masih belum cukup matang untuk dikatakan dewasa. Pada masa ini remaja tidak lagi merasa dibawah tingkat orang-orang yang lebih tua melainkan berada dalam tingkat yang sama. Awal masa remaja adalah berlangsung pada usia 13 sampai 17 tahun (Hurlock, 1980: 206).

Hurlock (1980: 212) menjelaskan bahwa masa remaja dianggap sebagai periode "badai dan tekanan". Suatu masa dimana ketegangan emosi meninggi sebagai akibat dari perubahan fisik dan kelenjar. Tidak semua remaja mengalami masa badai dan tekanan, namun benar juga bila sebagian besar remaja mengalami tidak kestabilan dari waktu ke waktu sebagai konsekuensi usaha penyesuaian diri terhadap pola perilaku baru dan harapan sosial baru.

Proses penyesuaian diri diperlukan individu untuk memasuki situasi dan kondisi lingkungan yang baru dan tentu saja hal tersebut dialami oleh siswa di sekolah. Hal ini ditegaskan oleh Sunarto \& Hartono (2008: 222-224) penyesuaian diri adalah proses bagaimana individu mencapai keseimbangan diri dalam memenuhi kebutuhan sesuai dengan lingkungan. Jika individu dapat berhasil memenuhi kebutuhannya sesuai dengan lingkungannya dan tanpa menimbulkan gangguan atau kerugian bagi lingkungannya, hal itu disebut "well adjusment" atau penyesuaian diri yang baik. Dan sebaliknya jika individu gagal dalam proses penyesuaian diri disebut "maladjustment" atau penyesuaian diri yang salah.

Ramanda \& Ramdani (2016: 16) mengemukakan bahwa penyesuaian diri yang salah terjadi apabila individu bersangkutan tidak dapat melakukan penyesuaian secara normal. Perilaku penyesuaian diri yang salah ditandai dengan berbagai bentuk tingkah laku yang salah, tidak terarah, emosional, sikap yang tidak realitas dan agresif. Penyesuaian diri yang salah dipandang sebagai ketidak efektifan individu dalam menghadapi, menanggapi atau melaksanakan tuntutantuntutan dari lingkungan fisik dan sosialnya maupun bersumber dari kebutuhan dirinya sendiri. Karena kemampuan remaja dalam menyesuaikan diri ini dipengaruhi faktor y aitu kecerdasan emosi. Fatimah, (dalam Karmiana 2016: 5) 
faktor yang mempengaruhi adalah kecerdasan emosi. Emosi merupakan salah satu karakteristik seseorang terhadap lingkungannya. Untuk dapat melakukan penyesuaian diri yang baik dan terhindar dari perilaku penyesuaian diri yang salah, kecerdasan emosi mempunyai peranan yang sangat penting. Karena siswa yang matang secara emosional lebih dapat diterima dalam lingkungan sosialnya. Hal ini sejalan dengan penjelasan Uno (2006: 71) bahwa kecerdasan emosilah yang memotivasi seseorang untuk mencari manfaat dan mengaktifkan aspirasi dan nilai-nilai yang paling dalam, mengubah apa yang dipikirkan menjadi apa yang dijalani. Jadi, kecerdasan emosional adalah kemampuan merasakan, memahami, dan secara efektif menerapkan daya dan kepekaan emosi sebagai pengaruh lingkungan.

Kenyataannya banyak kasus yang ditemukan di SMP Negeri 6 Kota Bengkulu yaitu masih adanya sebagian siswa usia remaja yang tidak dapat mengelola kecerdasan emosinya secara efektif, sehingga masih banyak remaja yang gagal dalam penyesuaian diri. Remaja yang menunjukkan perilaku penyesuaian diri yang salah akan cenderung mengalami kehidupan yang kurang bahagia seperti siswa yang dikucilkan teman sebayanya sehingga siswa selalu dalam keadaan cemas dan tidak tenang, siswa yang kurang percaya diri saat berbicara di depan teman-temanya dan siswa kurang percaya diri saat mengerjakan ulangan sehingga siswa mencontek, siswa yang tertutup dan menyendiri menunjukkan kematangan emosional dan sosial yang kurang, sikap siswa yang cenderung kaku menimbulkan permusuhan, siswa tidak dapat mengontrol emosi dalam suatu permasalahan, terdapat kelompok-kelompok kecil dalam kelas yang menimbulkan perpecahan antar siswa di kelas, dan siswa yang agresif seperti berkelahi dan bolos sekolah.

Jhon Dewey (dalam Hasbullah, 2009: 2) mendefinisikan pendidikan adalah proses pembentukan kecakapan-kecakapan fundamental secara intelektual dan emosional ke arah alam dan sesama manusia, di setiap ada kehidupan manusia di situ ada pendidikan. Oleh karena itu, pendidikan adalah suatu usaha atau kegiatan yang dijalankan dengan sengaja, teratur dan berencana dengan maksud mengubah atau mengembangkan perilaku yang diinginkan. Untuk mengatasi perilaku 
tersebut guna mencapai tugas perkembangan yang baik pada masa remaja, peran layanan bimbingan dan konseling adalah membantu siswa mengenali perasaan diri sendiri maupun orang lain sehingga siswa terhindar dari penyesuaian diri yang salah, serta membantu mengelola emosi siswa dengan baik. Dengan begitu, siswa mampu mengurangi perilaku penyesuaian diri yang salahdan siswa mampu mengembangkan sikap positif terhadap dirinya sendiri sehingga dapat menyesuaikan diri terhadap lingkungannya.

Berdasarkan uraian yang telah dipaparkan di atas, perlu diadakan penelitian dengan judul "Hubungan Antara Kecerdasan Emosi Dengan Perilaku Penyesuaian Diri Yang Salah Pada Siswa Kelas VIII di SMP Negeri 6 Kota Bengkulu”.

\section{Metode Penelitian}

Desain penelitian yang digunakan pada penelitian ini adalah desain korelasional. Darmadi (2014: 206) menyatakan bahwa penelitian korelasional adalah suatu penelitian yang dilakukan dengan mengumpulkan sejumlah data untuk mengetahui serta menentukan ada tidaknya hubungan antara dua variabel atau lebih, guna mengukur seberapa besarnya tingkat hubungan kedua variabel yang diukur tersebut. Pada penelitian ini, ingin mengetahui hubungan antara dua variabel yang akan dikaitkan, yakni variabel bebas (kecerdasan emosi) dan variabel terikat (penyesuaian diri yang salah) di SMP Negeri 6 Kota Bengkulu.

Sugioyono (2017: 61) menjelaskan bahwa populasi adalah wilayah generalisasi yang terdiri atas obyek/subyek yang mempunyai kualitas dan karakteristik tertentu yang ditetapkan oleh peneliti untuk dipelajari dan kemudian ditarik kesimpulannya. Populasi dalam penelitian ini adalah seluruh siswa/siswi kelas VIII di SMP Negeri 6 Kota Bengkulu sebanyak 171 orang. Dengan sampel penelitian sebanyak 120 orang yang diambil secara acak. Pengambilan sampel penelitian ini menggunakan teknik simple random sampling.Untuk menghitung besarnya ukuran sampel dapat dilakukan dengan menggunakan rumus Slovin (Sujarweni \& Endrayanto, 2012: 17) yaitu:

$$
n=\frac{N}{1+N e^{2}}==\frac{171}{1+171(0,05)^{2}}=\frac{171}{1,4275}=119,7 \approx 120 \text { Siswa }
$$


Teknik pengumpulan data menggunakan skala. Skala yang digunakan dalam penelitian ini ada dua macam yaitu skala kecerdasan emosi dan skala penyesuaian diri yang salah.

Teknik analisis data yang digunakan dalam penelitian ini adalah analisis data korelasi Pearson product moment untuk mencari arah dan kekuatan hubungan antara variabel bebas (kecerdasan emosi) dan variabel terikat (perilaku penyesuaian diri yang salah).

\section{Hasil dan Pembahasan}

Azwar (2012: 86) menjelaskan bahwa semua aitem yang mencapai koefisien korelasi minimal 0,30 daya bedanya dianggap memuaskan. Sedangkan aitem yang kurang dari 0,30 dapat di interpretasikan sebagai aitem yang memiliki daya beda rendah.

Berdasarkan item skala penyesuaian diri yang salah yang terdiri dari 60 pernyataan menunjukkan bahwa terdapat terdapat 47 item yang dinyatakan memuaskan. Dan terdapat 13 item yang dinyatakan rendah. Nilai Corrected ItemTotal Corelation koefisien terendah sebesar 0,385 dan koefisien tertinggi sebesar 0,762. Sementara item skala kecerdasan emosi yang terdiri dari 48 pernyataan menunjukkan bahwa terdapat 44 item yang dinyatakan memuaskan Dan terdapat 4 item yang dinyatakan rendah. Nilai Corrected Item-Total Corelation dengan koefisien terendah sebesar 0,403 dan koefisien tertinggi sebesar 0,864.

Uji reliabilitas pada penelitian ini menggunakan reliability analysis scale (Cronbach Alpha)dengan bantuan software SPSSversi 17.0 for windows. suatu data memiliki reliabilitas yang baik jika memenuhi syarat nilaiCronbach'sAlphaminimal 0,70. Nilai Cronbach Alpha penyesuaian diri yang salah sebesar $0,946(>0,7)$ dan kecerdasan emosi sebesar 0,967 $(>0,7)$ sehingga data memiliki tingkat reliabilitas yang baik. 
Tabel 1

Distribusi Frekuensi dan Kategorisasi Perilaku Penyesuaian Diri yang Salah

\begin{tabular}{cccc}
\hline Kategori & Rentang Skor & Frekuensi & Persentase \\
\hline Rendah & $44-102$ & 72 & $58,3 \%$ \\
\hline Sedang & $103-160$ & 47 & $39,1 \%$ \\
\hline Tinggi & $161-220$ & 1 & $0,83 \%$ \\
\hline
\end{tabular}

Berdasarkan pada Tabel 1 dapat dilihat bahwa sampel yang memiliki perilaku penyesuaian diri yang salah kategori tinggi sebanyak 1 orang $(0,83 \%)$, sampel yang memiliki perilaku penyesuaian diri yang salah kategori sedang sebanyak 47 orang $(39,1 \%)$, dan sampel yang memiliki perilaku penyesuaian diri yang salah kategori rendah sebanyak 72 orang $(58,3 \%)$. Dari data tersebut dapat diambil kesimpulan bahwa siswa kelas VIII di SMP Negeri 6 Kota Bengkulu memiliki perilaku penyesuaian diri yang salah kategori sedang.

Tabel 2

Distribusi Frekuensi dan Kategorisasi Kecerdasan emosi

\begin{tabular}{cccc}
\hline Kategori & Rentang Skor & Frekuensi & Persentase \\
\hline Rendah & $47-109$ & 0 & $0 \%$ \\
\hline Sedang & $110-172$ & 99 & $82,5 \%$ \\
\hline Tinggi & $173-235$ & 21 & $17,5 \%$ \\
\hline
\end{tabular}

Berdasarkan pada Tabel 2 dapat dilihat bahwa sampel yang memiliki kecerdasan emosi kategori tinggi sebanyak 21 orang (17,5\%), sampel yang memiliki kecerdasan emosi kategori sedang sebanyak 99 orang $(82,5 \%)$, dan sampel yang memiliki kecerdasan emosi kategori rendah sebanyak 0 (0\%). Dari data tersebut dapat diambil kesimpulan bahwa siswa kelas VIII di SMP Negeri 6 Kota Bengkulu memiliki kecerdasan emosi kategori sedang.

Sebelum melakukan pengujian hipotesis, terlebih dahulu harus dilakukan uji prasyarat. Pengujian prasyarat analisis bertujuan untuk melihat apakah data 
penelitian yang didapat memenuhi syarat untuk analisis dengan menggunakan teknik korelasi product moment. Normalitas besarnya data masing-masing variabel dilihat dari kriteria jika sig $>0,05$ maka data berdistribusi normal. Jika sig $<0,05$ maka data tidak berdistribusi normal.

Hasil uji normalitas pada variabel variabel perilaku penyesuaian diri yang salah sebesar 0,651 dengan p>0,05sedangkan kecerdasan emosi menunjukkan nilai sebesar 0,308 dengan $\mathrm{p}>0,05$. Berdasarkan hasil tersebut data pada variabel perilaku penyesuaian diri yang salah dan kecerdasan emosi berdistribusi normal dan memenuhi syarat untuk dilakukan uji hipotesis menggunakan rumus korelasi product moment.

Berdasarkanhasil uji hipotesis menggunakan teknik product moment, hasil perhitungan korelasi antara perilaku penyesuaian diri yang salah dengan kecerdasan emosi dapat dilihat bahwa koefisien korelasi $\left(r_{x y}\right)$ sebesar $-0,402$ dengan $\mathrm{p}$ sebesar $0,000(\mathrm{p}<0,05)$, sehingga terdapat hubungan negatif yang signifikan antara kecerdasan emosi dengan perilaku penyesuaian diri yang salah. Dengan demikian hipotesis awal yang menyatakan kecerdasan emosi memiliki hubungan dengan perilaku penyesuaian diri yang salah pada siswa diterima. Artinya semakin tinggi kecerdasan emosi maka semakin baik perilaku penyesuaian diri yang salah, begitu pula sebaliknya semakin rendah kecerdasan emosi maka semakin tinggi perilaku penyesuaian diri yang salah.

Sundari (dalam Nadri, 2008: 23)menyatakan ada tujuh faktor yang menjadi penyebab terjadinya perilaku penyesuaian diri yang salah, yaitu : (1) Kasih sayang orang tua, (2) Broken homes, (3) Lingkungan, (4) Norma-norma sosial tertentu,(5) Pertumbuhan, (6) Persoalan pribadi, (7) Adanya kecacatan.

Kasih sayang orang tua terhadap putra putrinya tidak dapat diganti oleh siapapun. Juga secara kodrat sangat butuh perlindungan kasih sayang, karena demi kelangsungan hidupnya. Pencurahan kasih sayang itu tidaklah mudah, malainkan harus disesuaikan dengan jalannya perkembangan. Kasih sayang yang berlebih-lebihan orang tua terhadap anak, misalnya perlindungan agar terhindar dari kesulitan-kesulitan anak, sehingga anak selalu ditolong dalam segala hal, akhirnya anak tidak dapat mandiri. Anak akan selalu ragu-ragu dan takut, tidak 
percaya pada kekuatan sendiri. Anak dapat menjadi penurut, patuh tidak punya pendirian. Dan menjadi anak yang ingin berkuasa, menjelajah, egoistis. Bila mengahadapi kesulitan, penyesuaian diri ini tidak baik sehingga terjadi Maladjusment.

Broken homes, keluarga yang retak atau perceraian akan sangat terasa menimpa anak-anaknya, anak-anak akan memilih pada ayah atau ibu, atau tidak memilih keduanya. Disharmoni dalam keluarga membuat anak binggung dan selalu ragu-ragu, serta timbul perasaan malu dalam dirinya. sehinggadalam diri anak akan timbul konflik-konflik penyesuaian diri, yaitu mengalami kesulitan bahkan memungkinkan mengalami kegagalan. Sedangkan lingkungan, lingkungan keluarga merupakan lingkungan utama yang sangat penting. Unsur-unsur dalam keluarga seperti interaksi orang tua dengan anak, interaksi antar anggota keluarga, peran sosial dalam keluarga dan gangguan dalam keluarga akan berpengaruh terhadap penyesuaian diri individu. Sebagaimana lingkungan keluarga, lingkungan sekolah juga dapat menjadi kondisi yang memungkinkan berkembang atau terhambatnya proses perkembangan penyesuaian diri. Umumnya sekolah dipandang sebagai media yang sangat berguna untuk mempengaruhi kehidupan dan perkembangan intelektual, sosial, nilai-nilai, sikap dan moral manusia.

Norma-norma sosial tertentu, individu mempunyai berbagai dorongan yang harus mendapatkan kepuasan. Karena norma-norma sosial tertentu manusia itu tidak begitu mudah untuk memenuhinya. Misalnya dorongan seks dan hawa nafsu. Norma- norma yang membatasi kepuasan individu itu dapat menjadi rintangan yang selalu mengganggu keseimbangan. Karena norma-norma penyesuaian masing-masing individu dapat terganggu. Dan pertumbuhan, pada masa menginjak masa puber kurang lebih usia 13-17 tahun akan mengalami perubahan jasmani. Perstiwa ini menggelisahkan individu, individu yang semulanya lincah, kini terbatas geraknya menjadi malu. Sehingga menimbulkan ketidak sempurnaan dalam penyesuaian diri atau terjadi penyesuaian diri yang salah.

Persoalan pribadi, terutama pada masa puber,individu mempunyai problemproblem pribadi yang tidak dapat diungkapkan kepada siapapun, sebab takut kalau 
rahasia hidupnya diketahuai orang lain. Problem ini misalnya problem pemilihan jodoh, selain menimbulkan kesulitan bagi remaja itu sendiri, juga sering menimbulkan ketegangan orang tua. Orang tua yang tidak setuju dengan pilihan anaknya kadang-kadang malah mempercepat perkawinan tanpa perhitungan ekonomi akhirnya rumah tangganya berantakan, timbul penyesalan dan kecemasan yang berlarut-larut. Dan selanjutnya yaitu adanya kecacatan, cacat pada mental yang berat tidak begitu terasa bagi yang bersangkutan. Cacat mental sering akan terasa kecanggungan dalam penyesuaian diri. Cacat jasmani atau kurang sempurnananya jasmani sering menimbulkan perasaan harga diri kurang, sebab ada beberapa hal yang tidak dapat dikuasai atau tidak mampu untuk mengerjakan-nya demikianlah antara lain sebab-sebab timbulnya maladjusment(perilaku penyesuaian diri yang salah).

Sedangkan menurut Goleman (1996: 268) ada tiga faktor yang dapat mempengaruhi tinggi rendahnya kecerdasan emosi seseorang, yaitu: (1) faktor keluarga, (2) faktor lingkungan, (3) faktor Psikologis.

Keluarga merupakan sekolah pertama untuk mempelajari emosi. Kebanyakan orang-tua memperlakukan anak-anaknya dengan disiplin yang keras atau pemahaman yang empatik, serta bertanggung jawab, dan mempunyai sikap kepedulian terhadap siapapun. Sedangkanlingkungan, adalah cara untuk mengetahui berbagai emosi dari pergaulan yang dirinya dapatkan dari lingkungan yaitu dengan cara anak berperan sebagai individu di luar dirinya dengan emosi. Dan Psikologis, merupakan yang sangat penting untuk membantu individu dalam mengelola, mengontrol, mengendalikan dan mengkoordinasikan keadaan emosi agar selalu berperilaku secara efektif.

Hasil penelitian tersebut sejalan dengan teoriyang diungkapkan Salovey (Goleman, 1996: 58-59) bahwa kecerdasan emosi adalah kemampuan yang dimiliki oleh seseorang dalam mengenali emosi diri sendiri dan mengenali emosiorang lain, kemampuan memotivasi diri sendiri dan kemampuan mengelola emosi dengan baik, serta mampu membina hubungan dengan orang lain. Individu dengan keterampilan emosional yang berkembang baik berarti kemungkinan besar ia akan berhasil dalan penyesuaian diri serta mampu menguasai kebiasaan pikiran 
yang mendorong produktivitas individu tersebut. Sementara individu yang tidak dapat menghimpun kendali tertentu atas kehidupan emosionalnya akan mengalami pertarungan batin yang merampas kemampuan individu tersebut untuk memusatkan perhatian pada lingkungan sekitar.

Keterampilan dasar emosional tidak dapat dimiliki secara tiba-tiba, tetapi membutuhkan proses dalam mempelajarinya dan lingkungan yang membentuk kecerdasan emosi tersebut besar pengaruhnya. Adanya beberapa sikap individu di sekolah yang suka menyendiri, pendiam, dikucilkan teman, suka membolos dan malas belajar, karena individu tersebut belum memiliki kemampuan menyesuaikan diri dengan baikdan belum mampu mengelola kecerdasan emosi yang dimiliki dengan baik. Untuk membuat individu tersebut memiliki kemampuan dalam mengadakan penyesuaian diri dengan lingkungannya perlu adanya implus-implus yang kuat dan dorongan-dorongan insting, serta perlu adanya mekanisme yang dapat mengatur dan mengarahkan prilakunya menuju kemampuan penyesuaian diri dan diantara mekanisme yang diperlukan itu adalah kecerdasan emosi.

Hal ini sesuai dengan pendapat Sunarto \& Hartono (2002:227) bahwa kegagalan dalam melakukan penyesuaian diri secara positif, dapat mengakibatkan individu melakukan penyesuaian diri yang salah. Karena kemampuan remaja dalam menyesuaikan diri ini dipengaruhi oleh faktor yaitu kecerdasan emosi. Individu yang memiliki kecerdasan emosi yang tinggi dapat membuat individu menyesuaikan diri dengan baik dalam lingkungannya sehingga siswa mampu terhindar dari perilaku penyesuaian diri yang salah. Runyon dan Haber (dalam Karmiana, 2016: 53) juga menjelaskan bahwa setiap orang mengalami masalah dalam mencapai tujuan hidupnya dan penyesuaian diri sebagai keadaan atau sebagai proses. Individu mengubah tujuan dalam hidupnya seiring dengan perubahan yang terjadi di lingkungan.Seorang individu di sekolah selain di tuntut untuk belajar, hendaknya harus memiliki kecerdasan emosi yang baik sehingga dapat bekerjasama menciptakan hubungan interpersonal yang baik, dan dapat menyelaraskan dirinya dengan lingkungan sekolah. 
Kecerdasan emosi bermanfaat bagi proses penyesuaian diri individu. Kecerdasan emosi juga sangat berguna karena dalam proses penyesuaian diri, seorang individu diharuskan untuk mampu berlaku sesuai dengan apa yang menjadi keinginan dari lingkungan sosialnya. Jika individu tersebut dapat memahami betul bagaimana keadaan yang ada di sekitarnya, maka secara otomatis pasti akan mengerti perlakuan apa yang harus dilakukan agar sesuai dengan keadaan lingkungan tersebut. Dengan memiliki kemampuan kecerdasan emosi yang tinggi, individu akan mampu menyesuaikan diri dan terhindar dari perilaku penyesuaian diri yang salah. Hal ini selaras dengan pendapat Salovey (Goleman, 1996: 58-59) hal yang terpenting dalam menyesuaikan diri adalah kecerdasan emosi, yaitu kemampuan yang dimiliki oleh individu dalam mengenali emosi diri sendiri dan mengelola emosi, kemampuan memotivasi diri sendiri dan kemampuan mengenali emosi orang lain dengan baik, serta mampu membina hubungan dengan orang lain. Seorang individu yang matang emosinya mampu bersikap realistik dan objektif serta memiliki keterampilan hubungan intrapesonal dan interpersonal yang baik pula.

Pada penelitian ini, peneliti hanya meneliti hubungan antara kecerdasan emosi dengan perilaku penyesuaian diri yang salah. Hasil penelitian ini hanya terbatas pada siswa kelas VIII tidak untuk kelas lain. Hasil penelitian ini tidak berlaku untuk di sekolah lain karena populasi hanya untuk kelas VIII di SMP Negeri 6 Kota Bengkulu.

\section{Kesimpulan}

Kecerdasan emosi pada siswa kelas VIII di SMP Negeri 6 Kota Bengkulu tergolong dalam kategori sedang.Perilaku penyesuaian diri yang salah pada siswa kelas VIII di SMP Negeri 6 Kota Bengkulu tergolong dalam kategori sedang.Terdapat hubungan negatif yang signifikan antara kecerdasan emosi dengan perilaku penyesuaian diri yang salah di SMP Negeri 6 Kota Bengkulu. Artinya semakin tinggi kecerdasan emosi maka semakin rendah perilaku penyesuaian diri yang salah pada siswa. 


\section{Daftar Pustaka}

Azwar, S. (2012). Penyusunan Skala Psikologi. Yogyakarta: Pustaka Pelajar.

Darmadi. (2014). Metode Penelitian Pendidikan dan Sosial. Bandung: Remaja Rosdakarya.

Goleman, D. (1996). Emotional Intelligence. Jakarta: Gramedia Pustaka Utama.

Hasbullah. (2009). Dasar-Dasar Ilmu Pendidikan. Jakarta: Raja Grafindo.

Hurlock, E.B. (1980). Psikologi Perkembangan. Jakarta: Erlangga.

Uno, H.B. (2006). Orientasi baru Dalam Psikologi Pembelajaran. Jakarta: Bumi Aksar

Karmiana, N. (2016). Hubungan Antara Kecerdasan Emosi Dengan Penyesuaian Diri Mahasiswa Perantau Asal Lampung. (Skripsi tidak dipublikasikan). Fakultas Psikologi Universitas Muhamadiyah Surakarta, Surakarta.

Nadri. (2013). Peran Guru Bimbingan dan Konseling Dalam Mengatasi Maladjustment Pada Siswa SMA Handayani Pekan Baru.(Skripsi tidak dipublikasikan). Bimbingan Konseling Islam (BKI) Fakultas Dakwah dan Ilmu Komunikasi Universitas Islam Negeri Sultan Syarif Kasim Riau, Pekan Baru.

Ramanda, P \& Ramdani. (2016). Upaya Meningkatkan Penyesuaian Sosial Anak Asuh Usia Remaja Di Panti Asuhan. Jurnal Kopasta. 3(1), 14-22.

Sugiyono. (2017). Statistika Untuk Penelitian. Bandung: Alfabeta.

Sujarweni dan Poly E. (2012). Statistik Untuk Penelitian. Yogyakarta: Graha Ilmu.

Sunarto, \& Agung H. (2008). Perkembangan Peserta Didik. Jakarta: Rineka Cipta. 